\title{
Compensation and Organizational Commitment: The Mediating Role of Job Satisfaction
}

\author{
Muhammad Irfan Nasution', Muhammad Andi Prayogi ${ }^{2}$, Jufrizen $^{3}$, \\ Delyana Rahmawany Pulungan ${ }^{4}$, Azuar Juliandi ${ }^{5}$ \\ \{muhammadirfan@umsu.ac.id ${ }^{1}$, muhammadandi@umsu.ac.id², jufrizen@umsu.ac.id ${ }^{3}$, \\ delyanarahmawany@umsu.ac.id ${ }^{4}$,azuarumsu@gmail.com ${ }^{5}$ \} \\ $1,2,3,4,5$ University of Muhammadiyah Sumatera Utara \\ Jalan Kapten Mukhtar Basri No. 3, Medan, Indonesia
}

\begin{abstract}
The compensation and job satisfaction given by the company will be closely related to the commitment of the organization of Medical Representative, the purpose of this research is analyze partially the effect of compensation on organizational commitment, and analyze whether job satisfaction able to mediate between compensation and organizational commitment. Sampling using the sampling quota 100 Medical Representative in Medan City, This research uses data analysis technique with path analysis. The result of this research shows that compensation has positive and significant effect on job satisfaction, compensation has positive and significant effect on organizational commitment, and job satisfaction has positive and significant influence on organizational commitment, job satisfaction able to mediate the influence of compensation to organizational commitment, in other words, job satisfaction as variable intervening. The company must provide compensation in accordance with the work performed by the medical representative and the company must be able to provide job satisfaction to the Medical Representative so that the target given by the company can be achieved.
\end{abstract}

Keywords: Compensation, job satisfaction, organizational commitment

\section{Introduction}

Important commitments were owned by each individual who works at the company, due to the commitment of individual psychology one of the conditions or conditions between employees and the company are related to staying afloat in the company, so that employees do not leave the company on any condition of the company, any current will have a commitment to each other different languages, this is yan will cause difficulties in the company will retain employees aga remains committed. Agreed with researcher (Onsardi, et al., 2017; Dirani, 2014; Alamelu, 2015) that organizational commitment is one of the important factors that exist within the company, had committed employees will take the company in a competitive work environment. At the pharmaceutical company mainly Medical Representative who is one of the mainstays of the company, employees should always improve service to consumers, as it says Nguyen, et al., (2014) choose remains committed on the company because the company is the place for them to earn an income.

Robbins, (2003) said that the degree to which an employee identifies with a particular organization and its goals, and wishes to maintain membership in the organization. Then Allen \& Mayer, (1990) finds three types of organizational commitment; (1) affective Commitment, means an emotional attachment and employee engagement within the organization, so the employees will stick to the company because of their own desires, (2) the Continuous Commitment means that the employee will stay with the company because only the needs, (3) 
normative Commitment, employees will stay with the company because of the form of responsibility and loyalty to the company. These three types are up to now used by researchers in measuring employee commitment as in research (Anton, 2009; Triana, 2017; Supriyadi et al., 2017; Kawka, 2014).

Medical Representative is a term for employees of Pharmaceutical Companies in the field of marketing, In Medan City, Some pharmaceutical companies use medical representatives to promote products to consumers. Medical representatives will get sales targets, the number of targets obtained each individual differs depending on the company, the results of observations made the authors found that some of these medical representatives who do not achieve targets set by the company, individuals like this will choose not committed to the company because they did not reach the target, did not get the bonus, and always get pressure from the leader, so they chose not to commit and will look for a new company. Medical Representative who reaches the target company in every month there is also a vote not committed to the company because of the salary and facilities they earn still not meet the daily needs. This makes the author to be interested in doing research, why the Medical Representative who reached the target still feel not committed to the company with the results that have been obtained. So this research will analyze whether there is the influence of compensation and job satisfaction to commitment of Medical Representative, either direct or indirect influence. There are several factors that cause Medical representative does not have a commitment to the company such as is not getting compensation both financial and nonfinancial has not sufficient needs and job satisfaction they have not gained on the company. Findings in the field in line with said Anton, (2009) the uncertainty of work experienced by employees will have an impact on organizational commitment.

Compensation is the amount received by employees for the services they have provided to the company, compensation may be salary, incentives, job allowances, prizes, and other facilities that are not in the form of money (Supriyadi et al., 2017). Likewise, as it is said Rianaa \& Wirasedanaa, (2016), compensation is one of the important things that should be given to employees to keep employees' commitment to stay engaged in any company activity, highly committed employees will work to achieve competitive advantage and will maintain customer relationships. (Rubel and Kee, 2015; Muguongo et al., 2015) revealed that inadequate compensation is the main cause of employee dissatisfaction that can cause another negative impact on companies such as, not in target and absenteeism therefore companies need to design better compensation. The research by (Eliyana, et al., 2012; Mabaso \& Dlamini, 2017; Salisu, et al., 2015; Onsardi et al., 2017) revealed that compensation has a positive and significant impact on job satisfaction, it is because the higher compensation will provide the stimulus to employees to work better than the low compensation (Winda et al., 2017)

Supriyadi et al (2017), said that attractive and high compensation will increase organizational commitment such as (Nawab and Bhatti, 2011; Silaban et al., 2018; Iresa et al., 2015; Alamelu et al, 2015) which concludes that compensation has a positive and significant effect on organizational commitment, this is because work works expecting rewards (Triana, 2017). Job satisfaction variable will give influence to organizational commitment this is proved by research (Anton, 2009; Gunlu et al., 2010; Tnay et al., 2013).

The interesting thing about this research is to place job satisfaction as a mediating variable or mediate the influence of compensation to organizational commitment, yet many studies use job satisfaction variable as the intervening variable, whereas previous research emphasizes organizational commitment variable as the intervening variable, (Anis et al., 2011). The level of job satisfaction devised for each employee will be different, the more 
aspects that fit the employee's desire, the higher the level of perceived satisfaction (Ghofur et al., 2017).

Based on the explanation that has been presented, the conceptual framework of this research is shown in Figure 1.



Fig. 1. Conceptual framework.

From the description above, the hypothesis can be formulated as H1: Compensation has a direct positive effect on Job satisfaction. H2: Compensation has a direct positive effect on Job satisfaction organizational commitment. H3: There is an indirect influence between compensation for organizational commitment mediated by job satisfaction.

\section{Methods}

The approach of this research is a quantitative method by doing survey questionnaire which measured using Likert scale 1-5. The indicators used in this study refer to the research from (Tarigan \& Ariani, 2015), which explains the five indicators used to measure compensation namely; (1) appropriate salaries, (2) bonuses, (3) incentives, (4) benefits, (5) rewards.

The indicators used for organization commitments refers to the research by (Supriyadi et al., 2017; Thomas, et al., 2008), namely; (1) the affective commitment, (2) continuance commitment, (3) normative commitment. The indicators used in job satisfaction refers to (Winda et al., 2017; Onsardi et al., 2017), namely; (1) fun Job, (2) appropriate gifts, (3) working conditions, (3) colleagues, and (4) personal suitability work.

The sample of this research is Medical Representative who works in Pharmaceutical Company in Medan City; sampling is done with saturation sampling as much as 100 respondents. Prior to the questionnaire, the questionnaire validity and reliability of the questionnaire were done with product moment correlation, the result of the validates test shows $t_{\text {count }}>t_{\text {table }}(0.1966)$, so that the number of items of the instrument can be said to be valid. While the reliability test using Cronbach alpha shows the value of variable compensation of 0.820 , job satisfaction of 0.830 and organizational commitment of, because the value of Cronbach alpha is greater than 0.797 then the three variables can be reliably labeled, which means the questionnaire of this study is feasible for use in subsequent testing. The data analysis used in this study is the path analysis.

\section{Results}

\subsection{The regression coefficients in the Model Equations I}

Regression in equation model I (direct influence X1 and X2) is used to determine the value of $\mathrm{P} 1$, and Pe1. The equation model is X2: X1 + e1. From Table 1 in the Standardized Coefficients column the regression coefficient value is $\mathrm{x} 1=\mathrm{P} 1=0.746$ (hence this value will be inserted into the analysis diagram). 
Table 1. Model Regression I.

\begin{tabular}{ccccccc}
\hline \multirow{2}{*}{ Model } & \multicolumn{2}{c}{$\begin{array}{c}\text { Unstandardized } \\
\text { Coefficients }\end{array}$} & $\begin{array}{c}\text { Standardized } \\
\text { Coefficients }\end{array}$ & & Sig. \\
\cline { 2 - 5 } & $\mathrm{B}$ & Std. Error & Beta & & \\
\hline (Constant) & 7,061 & 3,759 & & 1,878 &, 063 \\
\hline Compensation &, 979 &, 088 &, 746 & 11,078 &, 000
\end{tabular}

a.Dependent variable: Job satisfaction

In Table 2, the Summary Model of Adjusted R Square value is 0.551 . This value can be used to determine the value of the path coefficient with the residual ie Pel $=\sqrt{ }\left(1-R^{2}\right),=\sqrt{ }(1-$ $0,551)=0,6700$ (hence this value is entered into the path analysis diagram).

Table 2. Model Summary

\begin{tabular}{cccc}
\hline Model R & \multicolumn{2}{r}{$\begin{array}{c}\text { R Square Adjusted } \\
\text { Square }\end{array}$} & $\begin{array}{c}\text { RStd. Error of the } \\
\text { Estimate }\end{array}$ \\
\hline $1 \quad, 746^{\mathrm{a}}, 556$ &, 551 & 3,77600 \\
\hline \multicolumn{2}{c}{ a. Predictors: (Constant), Compensation (X1) } \\
\hline
\end{tabular}

From the result of regression coefficient calculation in equation I can be seen in Figure 1 regression model in the equation I.

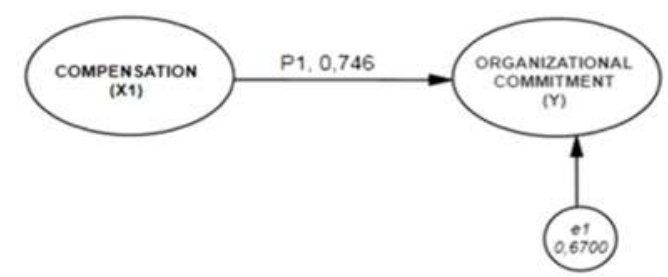

Fig. 2. Regression Model I.

\subsection{Regression Coefficient in Equation Model II}

Regression in equation model II (direct influence $\mathrm{X} 1$ and $\mathrm{X} 2$ to $\mathrm{Y}$ ) is used to determine the value of P2 and Pe2. The model is $\mathrm{Y}: \mathrm{P} 2 \mathrm{X} 1+\mathrm{P} 3 \mathrm{X} 1+\mathrm{Pe} 2$. From Table 3 of the Standardized Coefficients column the value of the regression coefficient is $\mathrm{X} 1=\mathrm{P} 2=0.618$ (this value will be included in the path analysis diagram) the coefficient $\mathrm{X} 2=\mathrm{P} 3$ is 0.348 (hence this value will be included in the path analysis diagram).

Table 3. Model Regression II.

\begin{tabular}{|c|c|c|c|c|c|}
\hline \multicolumn{2}{|r|}{ Model } & \multicolumn{2}{|c|}{$\begin{array}{l}\text { Unstandardized } \\
\text { Coefficients }\end{array}$} & \multirow{2}{*}{$\begin{array}{c}\begin{array}{c}\text { Standardized } \\
\text { Coefficients }\end{array} \\
\text { Beta } \\
\end{array}$} & \multirow[t]{2}{*}{ t Sig. } \\
\hline & & B & Std. Error & & \\
\hline \multirow[t]{3}{*}{1} & (Constant) & 6,060 & 1,722 & & $3,520,001$ \\
\hline & Compensation (X1) &, 576 &, 060 & ,618 & $9,645,000$ \\
\hline & $\begin{array}{c}\text { Job Satisfaction } \\
(\mathrm{X} 2)\end{array}$ &, 247 &, 045 & ,348 & $5,439,000$ \\
\hline
\end{tabular}


number of samples $-2=100-2=98$, with the provision is obtained $\mathrm{F}$ table of $=3.09$ calculation results obtained the number $F$ count of $226.165>3.09\left(\mathrm{~F}_{\text {table }}\right)$, it can be concluded that there is a linear relationship between compensation, job satisfaction and organizational commitment, thus the regression model used in this study is feasible and correct.

After the calculation using path analysis, the next test path analysis could be seen as follows:

1. The direct effect of compensation on job satisfaction of 0.746 .

2. The direct influence of Job satisfaction on organizational commitment of 0.618.

3. The direct effect of compensation on organizational commitment of 0.346

4. Indirect influence between compensation to commitment through job satisfaction, seen from multiplication between regression coefficient value $\mathrm{X} 1$ to $\mathrm{X} 2$ with regression coefficient value $\mathrm{X} 2$ to $\mathrm{Y}$ is that $\mathrm{P} 1 \times \mathrm{P} 3(0,746 \times 0618)=1,$,364 .

5. Effect of total effect $\mathrm{X} 1$ to $\mathrm{Y}$ seen from the value of direct influence + indirect effect $=$ $0.348+1.364=1.712$.

\subsection{Hypothesis Test}

The test results using t-test to see the effect of compensation on job satisfaction, by looking at the tcount of $11.078>\mathrm{t}$ table of 1.66055 , with $\operatorname{sig} \alpha 0,000<0,05$, it can be stated Hypothesis 1 can be accepted thus compensation has a positive and significant impact on job satisfaction. Tests on Hypothesis 2 influence jobs satisfaction on organizational commitment, by looking at tcount 5,439> $\mathrm{t}$ table 1.66055 , with sig value $0,000<0,05$, it can be expressed Hypothesis 2 can be accepted thus job satisfaction have a positive and significant effect to organizational commitment. In Hypothesis 3 the effect of compensation on organizational commitment by looking at tcount of $9,645>t$ table equal to 1.66055 , with sig value 0,000 $<0,05$, hence can be expressed Hypothesis 3 can be accepted thus compensation have positive and significant effect to organizational commitment. Hypothesis 4 determine the indirect effect of compensation on organizational commitment through job satisfaction, by determining the coefficient of indirect effect $>$ direct influence $(\mathrm{P} 1 \mathrm{xP} 2)>\mathrm{P} 3$ ie $1.364>0.618$ Than X1 indirectly affect $\mathrm{Y}$ but must through $\mathrm{X} 2$, visible it is clear that $\mathrm{X} 2$ is a variable intervening / mediating relationship between $\mathrm{X} 1$ and $\mathrm{Y}$, meaning that it is so important role of job satisfaction in this research model, that job satisfaction becomes intermediary in increasing organizational commitment.

\section{Discussions}

\subsection{The Influence Between Compensation on Job Satisfaction}

The results of this study indicate that compensation has a positive and significant effect on job satisfaction. The level of compensation given by the company should be able to provide satisfaction to employees (Sopiah, 2013), this can be seen in Medical representative still finds employees with salary and income they earn yet get job satisfaction. Conditions like this will make employees look for other jobs with the income they expect. This research is in line with the researches by (Muguongo et al., 2015; Rubel and Kee, 2015; Winda et al., 2017; Salisu et al., 2015; Mabaso \& Dlamini, 2017) which concludes that compensation affects job satisfaction. The compensation given by the company should be better and comparable to the work of Medical Representative moreover, a good compensation will be able to improve employee work satisfaction. In addition, (Winda et al., 2017) mentions that good compensation will impact on satisfaction will be able to improve employee performance. 


\subsection{The Influence Between Job Satisfactions on Organizational Commitement}

Hypothesis 2 test results show that job satisfaction has a positive and significant impact on organizational commitment, this means that existing organizational commitment to employees can be improved if the desired job satisfaction Medical representative in accordance with the wishes, job satisfaction has an important role in the company to increase organizational commitment, the higher the employees' commitment to eating will provide better performance (Nasution, 2017). The results of this study are also in line with previous researches conducted by (Lamhanqin, et al., 2006; Gunlu et al., 2010; Nasution, 2017; Gunlu et al., 2010). The stimulus of job satisfaction needs to be given by the company to the employees in order to improve the organization as expressed by (Suma \& Lesha, 2013), that job satisfaction can be obtained from the work itself so as to increase organizational commitment.

\subsection{The Influence Between compensation on Organizational Commitment}

Hypothesis 3 in this study proves that compensation has a positive and significant influence on organizational commitment. An attractive compensation system will increase employee commitment, the compensation system given by the company should be able to create justice among its employees agree with (Milgo, et al., 2014) that says a good compensation system will increase organizational commitment by recognizing and rewarding employees with achievements and even providing stimuli to employees who have not achieved with rewards that employees can easily find. The results of this study agree with (Alamelu et al., 2015; Rianaa et al., 2016; Paik et al., 2007; Nawab et al., 2011) which states that satisfaction has significant influence on organizational commitment. The results of this study also show that compensation has the greatest contribution compared to other variables in this study, as said by Silaban et al., ( 2018) proper compensation provided by the company will be able to increase organizational commitment.

\subsection{The Influence of Compensation on Organizational Commitement to Job Satisfaction as Intervening Variable}

The results of Hypothesis 4 have no appropriate commitment but do not work, but are also the variables that mediate the influence between committed organizations, which is very advantageous in this research model, as well as job satisfaction become an institution with increasing organizational commitment. This study relevan with (Alamelu et al., 2015; Ghofur et al., 2017; Salisu et al., 2015), which states that the satisfaction variable can be a variable of mediation in increasing organizational commitment, and performance. Thus a job satisfaction hase an important role in the company. The companies must increase organizational commitment through job satisfaction by providing compensation of interest so that the Medical Representative will satisfied with the compensation they received. The compensation is only one of the media to increase employee commitment to work and can improve ownership in the company, employee commitment is an important factor in the company (Alamelu et al., 2015).

\section{Conclusions}

The results of this study prove that; (1) partial compensation and job satisfaction can affect organizational commitment, and (2) job satisfaction has an important role in this study because job satisfaction is able to mediate the relationship between compensation to 
organizational commitment. The implementation that can be done by the company is considering the compensation of interest and in accordance with the needs of medical representative. The compensation given by the company must refer to the desire, because in accordance with the workload of Medical representative. While the implications of the organization's own commitment that the company should be able to grow a sense of loyalty Medical Representative by increasing compensation and job satisfaction by providing programs that do not complicate Medical representative. In the future, similar research can be done by developing other variables in order to increase the company's competitive advantage and to strengthen the theory of scientific development.

\section{References}

[1] Alamelu, R., Surulivel, S. T., Motha, L. C. S., Amudha, R., \& Selvabaskar, S. (2015). Correlates of Employee Compensation and Commitment. Mediterranean Journal of Social Sciences, 6(5), 335-341. https://doi.org/10.5901/mjss.2015.v6n5p335

[2] Allen, N., \& Mayer, J. (1990). The Measurement and Antecendents of Affective, Continuance and Normative Commitment to The Organization. Journal of Occupational Psychology, 63(1), 1-18.

[3] Anis, A., Kashif-ur-Rehman, Ijaz-Ur-Rehman, Khan, M. A., \& Humayoun, A. A. (2011). Impact of organizational commitment on job satisfaction and employee retention in pharmaceutical industry. African Journal of Business Management, 5(17), 7316-7324. https://doi.org/10.5897/AJBM10.1296

[4] Anton, C. (2009). The impact of role stress on workers' behaviour through job satisfaction and organizational commitment. International Journal of Psychology, 44(3), 37-41. https://doi.org/10.1080/00207590701700511

[5] Dirani, K. M. (2014). Human Resource Development International Measuring the learning organization culture, organizational commitment and job satisfaction in the Lebanese banking sector. Human Resource Development International, 12(2), 37-41. https://doi.org/10.1080/13678860902764118

[6] Eliyana, A., Yusuf, R. M., \& Prabowo, K. (2012). The Influence of Employee's Job Satisfaction Factors on Organizational Commitment. American Journal of Economics, 2(4), 141-144. https://doi.org/10.5923/j.economics.20120001.31

[7] Ghofur, M., Amboningtyas, D., Warso, M. M., \& Haryono, A. T. (2017). Effect Of Compensation, Organization Commitment And Career Developing On Employee Performance With Job Satisfaction As Intervening Variable (Empirical Study At Pt. Tri Sinar Purnamadi Semarang). Journal of Management, 3(3), 1-8.

[8] Gunlu, E., Aksarayli, M., \& Percin, N. S. (2010). Job satisfaction and organizational commitment of hotel managers in Turkey. International Journal of Contemporary Hospitality Management, 22(5), 693-717. https://doi.org/10.1108/09596111011053819

[9] Iresa, A. R., Utami, H. N., \& Prasetya, A. (2015). Pengaruh Konflik Kerja dan Stres Kerja Terhadap Komitmen Organisasional dan Kinerja Karyawan (Studi pada Karyawan PT. Telekomunikasi Indonesia, Tbk Witel Malang). Jurnal Administrasi Bisnis, 23(1), 1-10.

[10] Kawka, T. (2014). Naukowe The Relationship between How Compensation Is Configured and the Level and Components of Commitment to Work - Findings Based on Allen and Meyer' s Organisational Commitment Scale. Zeszyty Naukowe, Uniwersytet Ekonomiczny w Krakowie, 9(933), 81-94. https://doi.org/10.15678/ZNUEK.2014.0933.0906 
[11] Lamhanqin, T., Zhang, Q., \& Lam, T. (2006). Job satisfaction and organizational commitment in the Hong Kong fast food industry. International Journal of Contemporary Hospitality Management, 15(4), 214-220. https://doi.org/10.1108/09596110310475667

[12] Mabaso, C. M., \& Dlamini, B. I. (2017). Impact of Compensation and Benefits on Job Satisfaction. Research Journal of Business Management, 11(2), 80-90. https://doi.org/10.3923/rjbm.2017.80.90

[13] Milgo, A. C., Namusonge, G., Kanali, C., \& Makokha, E. N. (2014). Reward and Compensation as a Determinant of Employee Commitment: A Survey of Ktda Tea Factories in Kenya. European Journal of Business and Management, 6(15), 117-126.

[14] Muguongo, M. M., Muguna, A. T., \& Muriithi, D. K. (2015). Effects of Compensation on Job Satisfaction Among Secondary School Teachers in Maara Sub - County of Tharaka Nithi County, Kenya. Journal of Human Resource Management, 3(6), 47. https://doi.org/10.11648/j.jhrm.20150306.11

[15] Nasution, M. I. (2017). Pengaruh Stres Kerja, Kepuasan Kerja Dan Komitmen Organisasi Terhadap Turnover Intention Medical Representative. MIX: Jurnal Ilmiah Manajemen, 7(3), 407-428.

[16] Nawab, S., \& Bhatti, K. K. (2011). Influence of Employee Compensation on Organizational Commitment and Job Satisfaction: A Case Study of Educational Sector of Pakistan. International Journal of Business and Social Science, 2(8), 25-32.

[17] Nguyen, T. N., Mai, K. N., \& Nguyen, P. V. (2014). Factors Affecting Employees' Organizational Commitment-A Study of Banking Staff in Ho Chi Minh City, Vietnam. Journal of Advanced Management Science, 2(1), 7-11. https://doi.org/10.12720/joams.2.1.7-11

[18] Onsardi, Asmawi, M., \& Abdullah, T. (2017). The Effect Of Compensation, Empowerment, And Job Satisfaction On Employee Loyalty. International Journal of Scientific Research and Management, 05(12), 7590-7599. https://doi.org/10.18535/ijsrm/v5i12.03

[19] Paik, Y., Parboteeah, K. P., \& Shim, W. (2007). The relationship between perceived compensation, organizational commitment and job satisfaction: the case of Mexican workers in the Korean Maquiladoras. The International Journal of Human Resource Management, 18(10), 37-41. https://doi.org/10.1080/09585190701570940

[20] Rianaa, I. G., \& Wirasedanaa, I. W. P. (2016). The Effect of Compensation on Organisational Commitment and Employee Performance with the Labour Union as the Moderating Variable. Scientific Journal of PPI-UKM, 3(2), 83-88. https://doi.org/10.21752/sjppi-ukm/ses/a29082016

[21] Robbins, P. S. (2003). Perilaku Organisasi: Konsep, Kontroversi, dan Aplikasi Edisi Jakarta: Prenhalindo. (B. H. Alih Pujaatmika, Ed.) (Bahasa Ind). Jakarta: Prenhalindo.

[22] Rubel, M. R. B., \& Kee, D. M. H. (2015). High Commitment Compensation Practices and Employee Turnover Intention: Mediating Role of Job Satisfaction. Mediterranean Journal of Social Sciences, 6(6), 321-332. https://doi.org/10.5901/mjss.2015.v6n6s4p321

[23] Salisu, J. B., Chinyio, E., \& Suresh, S. (2015). The impact of compensation on the job satisfaction of public sector construction workers of jigawa state of Nigeria. The Business and Management Review, 6(4), 10-11.

[24] Silaban, N., Yanuar, T., \& Syah, R. (2018). The Influence of Compensation and Organizational Commitment on Employees ' Turnover Intention. IOSR Journal of 
Business and Management, 20(3), 1-6. https://doi.org/10.9790/487X-2003010106

[25] Sopiah. (2013). The Effect of Compensation toward Job Satisfaction and Job Performance of Outsourcing Employees of Syariah Banks in Malang Indonesai. International Journal of Learning \& Development, 3(2), 77-91. https://doi.org/10.5296/ijld.v3i2.3612

[26] Suma, S., \& Lesha, J. (2013). Job Satisfaction And Organizational Commitment: The Case Of Shkodra Municipality. European Scientific Journal, 9(17), 41-51. https://doi.org/10.1108/MRR-09-2015-0216

[27] Supriyadi, A., Sanusi, A., \& Manan, A. (2017). A Study on the Performance of Manufacturing Employees: Organizational Culture , Compensation , Organizational Commitment, and Organizational Citizenship Behavior. European Journal of Business and Management, 9(6), 32-43.

[28] Tarigan, V., \& Ariani, D. W. (2015). Empirical Study Relations Job Satisfaction, Organizational Commitment, and Turnover Intention. Advances in Management and Applied Economics, 5(2), 21-42.

[29] Thomas, W., Lau, T., \& Snape, E. (2008). Entrepreneurial Competencies and the Performance of Small and Medium Enterprises: An Investigation through a Framework of Competitiveness. Journal of Small Business \& Entrepreneurship, 21(3), 257-276. https://doi.org/10.1080/08276331.2008.10593424

[30] Tnay, E., Othman, A. E. A., Siong, H. C., \& Lim, S. L. O. (2013). The Influences of Job Satisfaction and Organizational Commitment on Turnover Intention. In Procedia Social and Behavioral Sciences (Vol. 97, pp. 201-208). Elsevier B.V. https://doi.org/10.1016/j.sbspro.2013.10.223

[31] Triana, Y. (2017). The Influence Of Compensation, Organizational Commitment And Career Path To Job Performance Employees. Jurnal of Applied Management (JAM), 68(1), 68-73.

[32] Winda, O., Nayati, U. H., \& Arik, P. (2017). Impact of Compensation and Benefits on Job Satisfaction. Research Journal of Business Management, 11(2), 80-90. https://doi.org/10.3923/rjbm.2017.80.90 